\title{
Analisis Kandungan Unsur dan Tingkat Kekerasan Pada Senjata Logam Koleksi Museum Tosan Aji Purworejo
}

\author{
R. Ahmad Ginanjar Purnawibawa \\ Program Studi Arkeologi, Fakultas Ilmu Pengetahuan Budaya, \\ Universitas Indonesia \\ Email: ahmadgpurnawibawa@gmail.com
}

\begin{abstract}
Abstrak : Tulisan ini membahas tentang teknologi senjata logam pada masa lampau. Penelitian ini menggunakan metode analisis kandungan unsur ( $x$-ray fluroscence) dan tingkat kekerasan (skala Mohs) pada 11 senjata logam dari Museum Tosan Aji. Senjata-senjata tersebut berupa keris, pedang, dan mata tombak. Hasil analisis unsur memperlihatkan bahwa dari 11 senjata yang dianalisis tidak terdapat senjata dengan kandungan unsur dan trace element yang sama. Selain itu, tidak ditemukan hubungan antara hiasan pamor pada senjata dengan kandungan unsur. Sementara pengukuran tingkat kekerasan menunjukkan adanya perbedaan tingkat kekerasan pada jenis dan tipe senjata tertentu, serta adanya hubungan antara tingkat kekerasan dengan proses pembuatan pada senjata keris.
\end{abstract}

Kata kunci : Keris, pedang, mata tombak, pamor, trace element

Abstract : This paper is focused on technology of ancient metal weapons. This research is using analysis of element ( $\mathrm{x}$ ray fluroscence) and hardness test (Mohs scale) method to analyze 11 weapons from Tosan Aji Museum. Those weapons are krises, sword and spear tips. Based on element analysis result, there is no similar element composition and trace element in 11 metal weapons. Furthermore, element analysis proved that weapon's pamor and it's element composition is unrelated. Other method, hardness test result shows there is difference hardness level in various kind and type of weapons. Hardness test result also shows there is relation between hardness level and forging processes in kris.

Keyword : Kris, sword, spear tips, pamor, trace element

\section{Pendahuluan}

\section{A. Latar Belakang}

Sejak masa prasejarah, kemampuan manusia untuk beradaptasi dengan lingkungannya terus berkembang. Hal tersebut ditunjukkan dengan teknologi yang terus berkembang. Puncak perkembangannya adalah penguasaan cara peleburan logam. Penggunaan logam segera menyebar dengan luas, menggeser peran batu dan tulang sebagai alat yang esensial bagi kehidupan manusia (Fagan, 1975: 291). Kemajuan di bidang teknologi ini mengakibatkan tata ekonomi dan tata masyarakat yang baru dalam segala kehidupan (Haryono, 1983: 459). Dampak paling besar adalah penggunaan alat logam dalam kegiatan bercocok tanam. Hasilnya manusia dapat mengerjakan lahan yang lebih luas dan lebih cepat (Fagan, 1975:291). Hal ini mendorong surplus produksi pangan. Menurut Soejono (1992), terdapatnya surplus dalam memenuhi kebutuhan hidup mengakibatkan meningkatnya jumlah penduduk dan tumbuhnya perkampungan kecil dengan tata kehidupan yang teratur (Prijono, 2000: 135).
Kondisi tersebut mendukung tumbuhnya spesialisasi pekerjaan, salah satunya adalah pandai besi. Pandai besi merupakan pekerjaan yang memerlukan perhatian penuh, sehingga tidak memiliki cukup waktu untuk menghasilkan makanan sendiri. Bagi pandai besi, keadaan masyarakat dengan kondisi surplus memungkinkan mereka untuk menetap dan bekerja dengan tenang. Karena itu pengetahuan metalurgi/ pengolahan logam juga dapat menjadi tolok ukur muncul dan berkembangnya peradaban (Childe, 1950: 7-8).

Bagi arkeolog, keberadaan artefak-artefak logam tersebut tentu sangat penting untuk menambah pengetahuan mengenai kehidupan manusia di masa lampau. Artefak logam sebagai hasil teknologi dapat dipakai untuk menjelaskan tingkah laku manusia melalui cara-cara pembuatannya (Prijono, 2002: 697). Walaupun perannya yang sangat penting, penelitian terhadap artefak logam harus dilakukan secara berhati-hati. Artefak logam yang ditemukan umumnya telah rusak akibat proses oksidasi, walaupun kadang ditemukan dalam keadaan 
baik. Umumnya logam emas dan tembaga dapat bertahan lebih lama dari pada besi (Fagan, 1975:285).

Dalam hal ini arkeologi memerlukan ilmu bantu untuk mempelajari artefak logam. Salah satu ilmu bantu yang dapat digunakan adalah metalurgi. Metalurgi merupakan cabang ilmu yang berkaitan dengan logam (Haryono, 1999: 2). Timbul Haryono memberi istilah ilmu bantu yang berkaitan dengan metalurgi sebagai “arkeometalurgi” (Haryono, 1983: 2). Dalam arkeometalurgi peran analisis sangat penting untuk mengidentifikasi teknologi logam yang digunakan pada masa lampau.

Umumnya beberapa atribut yang diteliti adalah asal bahan logam yang digunakan dan proses mendapatkannya, teknik yang digunakan dalam pengerjaan sebuah artefak logam dan tipologi terhadap jenis artefak logam. Analisis terhadap kandungan unsur dan teknik pembuatan pada artefak dapat digunakan untuk mengetahui atribut-atribut teknologi tersebut (Fagan, 1975: 293). Analisis logam bertujuan untuk mengetahui kelompok unsur logam yang diteliti (Haryono, 1983: 7). Dalam analisis kelompok unsur logam beberapa metode yang dapat digunakan adalah ring oven, difraksi sinar $\mathrm{x}$ (X-ray diffraction), dan pancaran sinar $\mathrm{x}(X$-ray fluorescence $)$. Sementara teknik pengerjaan artefak dapat diketahui menggunakan metode metalografi dan pengukuran kekerasan.

Salah satu jenis artefak logam yang ditemukan di Indonesia adalah senjata. Saat ini senjata logam tersebut lebih dikenal dengan sebutan Tosan Aji. Tosan berarti logam dan aji memiliki arti berharga/ mulia (Wibawa, 2008: 32). Beberapa senjata logam yang dikenal di Indonesia antara lain tombak, keris, pedang, wedung, rencong, badik, dan lain-lain (Wibawa, 2008: 6). Salah satu senjata tersebut adalah pedang. Pedang adalah senjata serupa pisau panjang. Di Indonesia pedang dikenal oleh hampir semua suku bangsa dengan ragam bentuk dan ciri khas tersendiri. Pedang umumnya berbentuk lurus dan memiliki tajaman pada satu sisi, walaupun pedang berlekuk juga kadang dijumpai (Solyom dan Solyom, 1978: 26). Ditinjau dari bentuk mata bilahnya, pedang dibagi menjadi dua golongan besar, yaitu pedang suduk dan pedang sabet.

Senjata lainnya yang dikenal luas adalah tombak. Tombak merupakan senjata logam yang dikenal luas seluruh bangsa di dunia (Harsrinuksmo, 2008: 476-
478). Pada mulanya tombak digunakan untuk berburu dan menghalau binatang buas. Kemudian fungsinya berkembang sebagai alat perang, benda upacara, dan pusaka.Bentuk mata tombak bermacam-macam, mulai pipih meruncing hingga bulat memanjang. Umumnya tombak terbuat dari besi baja dan terkadang diberi bahan pamor. Mata tombak yang dibuat sebagai tombak pusaka umumnya diberi hiasan gambar timbul pada mata bilahnya. Gambar timbul itu kemudian ditempeli lapisan emas, hiasan ini disebut kinatah emas.

Berbeda dengan pedang dan tombak yang dikenal di seluruh dunia, keris merupakan senjata logam yang hanya berkembang di Asia Tenggara, tersebar di Semenanjung Malaya, Indonesia, dan Filipina (Hamzuri, 1988: 1; Huda, 2010: 234-248; Moebirman, 1970: 9). Keris merupakan senjata genggam yang digunakan untuk menikam. Bentuk keris yang pipih memanjang dengan dua sisi tajaman dan ujung runcing sangat sesuai sebagai senjata tikam. Hal ini menyebabkan bentuknya berbeda dengan senjata yang digunakan untuk memotong atau menebas (Djomul, 1985: 22). Bentuk keris dapat dibagi menjadi dua tipe, yaitu keris lurus dan keris luk (bergelombang) (Huda, 2010: 50; Djomul, 1985: 22).

Di Indonesia beberapa museum memiliki koleksi senjata logam dalam jumlah yang cukup banyak antara lain; Museum Keprajuritan, Museum Keris, Museum Pusat Informasi Majapahit dan Museum Tosan Aji. Museum Tosan Aji merupakan museum yang khusus menyajikan koleksi jenis-jenis tosan aji/ senjata logam, walaupun seiring perkembangannya museum ini juga memamerkan koleksi arkeologis lainnya yang ditemukan di sekitar Purworejo. Koleksi senjata yang dimiliki berjumlah 1027 bilah senjata dan terdiri dari berbagai jenis senjata. Dengan perincian: keris 721 bilah, tombak 288 bilah, pedang 7 bilah, kujang 3 bilah, badik 3 bilah, pedang samurai/ katana 2 bilah, cundrik 1 bilah, granggang 1 bilah, dan jamblo 1 bilah.

Analisis terhadap senjata logam penting dilakukan untuk mengetahui teknologi pada masa lampau. Analisis yang dilakukan umumnya adalah analisis unsur, tingkat kekerasan, dan teknik pembuatan. Analisis unsur untuk mengetahui bahan yang digunakan pada proses pembuatan dan lokasi asli bahan melalui susunannya yang khas (trace element) (Goffer, 1980: 8-9). Analisis kekerasan cukup bermanfaat untuk menjelaskan pengerjaan artefak, 
terutama jika unsur-unsurnya telah diketahui (Haryono, 1999: 6).

\section{B. Rumusan Masalah}

Berdasarkan uraian di atas, setidaknya terdapat dua pertanyaan yang dapat dikemukakan.

1) Bagaimana kandungan unsur pada tiap jenis senjata pada masing-masing tipe?

2) Serta bagaimana tingkat kekerasan pada tiap jenis senjata pada masing-masing tipe?

Dengan menjawab kedua pertanyaan tersebut, dapat diketahui atribut kandungan unsur, trace element, dan tingkat kekerasan dari aspek teknologi sebuah senjata logam. Satu atribut lainnya, yaitu teknik pengerjaan, akan dijelaskan menggunakan hasil analisis kandungan unsur dan tingkat kekerasan yang dipadukan dengan sumbersumber tertulis.

\section{Metode}

\section{Klasifikasi Senjata}

Senjata yang dianalisis dalam penelitian ini memiliki bentuk yang berbeda-beda. Perbedaan ini berdasarkan dimensi ukuran (panjang, lebar, dan tebal) dan ciri tertentu pada keris. Ciri-ciri ini merupakan atribut khas pada keris yang memiliki hubungan dengan tangguh. Definisi tangguh adalah perkiraan gaya kedaerahan atau zaman dibuatnya sebuah senjata berdasarkan pengamatan terhadap jenis besi, pamor, dan bajanya, serta pasikutan-nya (kesan selintas garapan sebuah senjata) (Harsrinuksmo, 2008: 459; Huda, 2010: 90-91). Berdasarkan atribut yang dapat diamati tersebut, terdapat lima tangguh pada keris yang digunakan dalam penelitian ini. Selengkapnya dalam tabel berikut :

Dalam penelitian ini senjata yang dianalisis dibatasi sebanyak 11 bilah senjata. Koleksi yang dianalisis adalah delapan bilah keris, dua bilah mata tombak dan sebilah pedang. Senjata yang dipilih memiliki bentuk yang utuh dan tidak mengalami korosi maupun kerusakan lainnya sehingga data susunan unsur maupun tingkat kekerasan yang dikumpulkan lebih akurat. Pertimbangan lain adalah perkiraan periodisasi dari sampel. Pada senjata umum dikenal istilah tangguh atau perkiraan mengenai kapan senjata tersebut dibuat berdasarkan ciri-ciri fisik (Huda, 2010: 90-91). Koleksi yang dipilih berasal dari lima tangguh yang berbeda, yaitu Pajajaran, Majapahit, Pajang, Mataram, dan Kamardikan.

Untuk memudahkan proses penelitian, senjatasenjata tersebut dikelompokkan ke dalam 'jenis' dan 'tipe'. Spaulding (1953: 305) mengemukakan bahwa klasifikasi merupakan proses menemukan kombinasi dari atribut-atribut yang ada pada artefak (Watson, 1971: 127), sehingga untuk menentukan sebilah senjata termasuk ke

Tabel 1. Ciri-ciri tangguh pada senjata logam

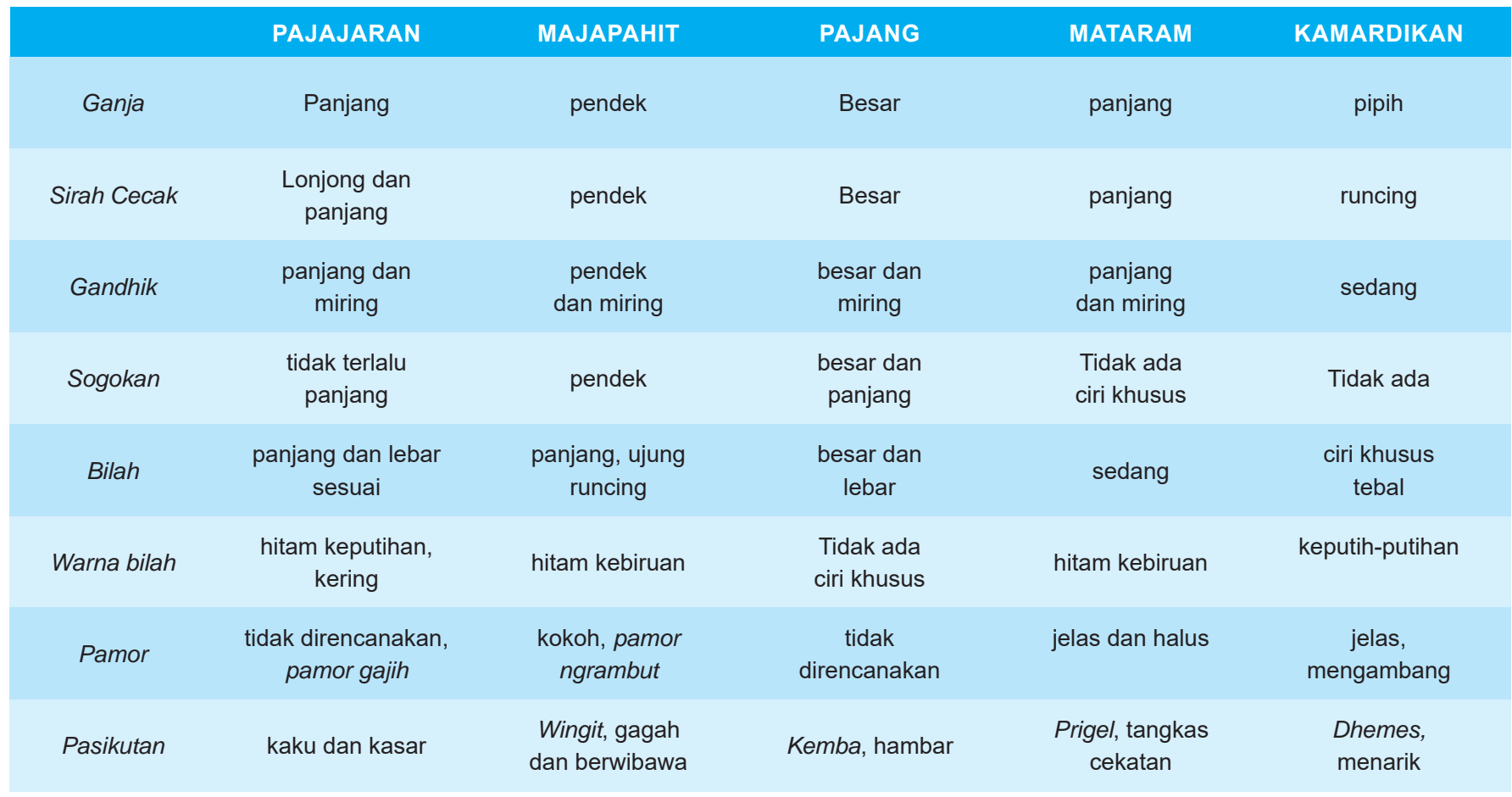


Tabel 2. Kombinasi atribut yang digunakan dalam menentukan jenis senjata

\begin{tabular}{|c|c|c|c|c|c|c|c|c|c|c|c|c|}
\hline \multirow{2}{*}{ NO. INVENTARIS } & \multicolumn{3}{|c|}{ UKURAN BILAH } & \multicolumn{3}{|c|}{ TAJAMAN } & \multicolumn{3}{|c|}{ BENTUK PESI } & \multicolumn{3}{|c|}{ JENIS SENJATA } \\
\hline & $\mathbf{P}$ & $L$ & $\mathbf{T}$ & V1 & V2 & V3 & $\mathbf{P}$ & $\mathbf{L}$ & $\mathbf{T}$ & Keris & Mata Tombak & Pedang \\
\hline 11.06/PWR/B/0003 & 36,5 & 1,8 & 0,4 & $\sqrt{ }$ & & & $\sqrt{ }$ & & & $\sqrt{ }$ & & \\
\hline 11.06/PWR/B/0011 & 61 & 3,2 & 0,5 & & $\sqrt{ }$ & & & & $\sqrt{ }$ & & & $\sqrt{ }$ \\
\hline 11.06/PWR/B/0036 & 23,3 & 2,4 & 0,3 & & & $\sqrt{ }$ & & $\sqrt{ }$ & & & $\sqrt{ }$ & \\
\hline 11.06/PWR/B/0038 & 44,5 & 1,4 & 0,3 & $\sqrt{ }$ & & & $\sqrt{ }$ & & & $\sqrt{ }$ & & \\
\hline 11.06/PWR/B/0048 & 35 & 2,1 & 0,2 & $\sqrt{ }$ & & & $\sqrt{ }$ & & & $\sqrt{ }$ & & \\
\hline 11.06/PWR/B/0069 & 35,7 & 1,8 & 0,2 & $\sqrt{ }$ & & & $\sqrt{ }$ & & & $\sqrt{ }$ & & \\
\hline 11.06/PWR/B/0120 & 22,1 & 3 & 0,9 & & & $\sqrt{ }$ & & $\sqrt{ }$ & & & $\sqrt{ }$ & \\
\hline 11.06/PWR/B/0352 & 33 & 2,2 & 0,2 & $\sqrt{ }$ & & & $\sqrt{ }$ & & & $\sqrt{ }$ & & \\
\hline 11.06/PWR/B/0386 & 34 & 2 & 0,3 & $\sqrt{ }$ & & & $\sqrt{ }$ & & & $\sqrt{ }$ & & \\
\hline 11.06/PWR/B/0395 & 35 & 2,2 & 0,2 & $\sqrt{ }$ & & & $\sqrt{ }$ & & & $\sqrt{ }$ & & \\
\hline 11.06/PWR/B/-- & 35,2 & 2,4 & 0,2 & $\sqrt{ }$ & & & $\sqrt{ }$ & & & $\sqrt{ }$ & & \\
\hline
\end{tabular}

dalam 'jenis' dan 'tipe' tertentu dilakukan pengamatan seksama pada senjata-senjata tersebut.Kombinasi atribut yang ditemukan dan digunakan untuk menentukan 'jenis' senjata adalah ukuran panjang dan lebar, bagian tajaman, dan bentuk pesi (bagian senjata yang ditancapkan pada gagang atau pegangan). Berdasarkan klasifikasi diketahui terdapat tiga jenis senjata yaitu; keris, mata tombak, dan pedang. Senjata yang termasuk jenis keris berjumlah delapan bilah, mata tombak berjumlah dua bilah, dan sebilah senjata termasuk dalam jenis pedang.

Selanjutnya sebelas bilah senjata yang telah terbagi ke dalam tiga jenis senjata, dikelompokkan lagi ke dalam 'tipe' berdasarkan kombinasi atribut yang lebih spesifik. Atribut-atribut tersebut adalah ganja, sirah cecak, gandhik, sogokan, bilah, warna bilah, dan pamor atau hiasan pada bilah senjata. Atribut-atribut tersebut merupakan bagian pada senjata yang dapat digunakan untuk menentukan masa pembuatan atau tangguh, tujuan digunakannya atribut-atribut tersebut adalah agar dapat membandingkan antara hasil pengelompokkan dalam penelitian ini dengan tangguh pada senjata. Hasilnya diketahui terdapat sembilan tipe senjata.

\section{Pancaran Sinar X (X-Ray Fluoroscence Spectrometry)}

Pancaran sinar x (X-ray fluorescence) merupakan metode analisis unsur tidak destruktif. Metode ini memiliki beberapa keunggulan dibandingkan metode lain, yaitu; tidak merusak, waktu analisis yang cepat, tidak memerlukan penyiapan sampel yang rumit dan biaya yang relatif lebih rendah. Metode pancaran sinar x (X-ray fluorescence) mampu mendeteksi kandungan unsur

\section{Tabel 3. Tipe senjata}

\begin{tabular}{|c|c|c|c|}
\hline NO. INVENTARIS & Keris & $\begin{array}{l}\text { ENIS SENJATA } \\
\text { Mata Tombak Pedang }\end{array}$ & TIPE \\
\hline 11.06/PWR/B/0003 & $\sqrt{ }$ & & Keris Tipe 1 \\
\hline 11.06/PWR/B/0038 & & $\sqrt{ }$ & Keris Tipe 2 \\
\hline 11.06/PWR/B/0048 & & $\sqrt{ }$ & Keris Tipe 3 a \\
\hline 11.06/PWR/B/0069 & $\sqrt{ }$ & & Keris Tipe 4 a \\
\hline 11.06/PWR/B/0352 & $\sqrt{ }$ & & Keris Tipe $3 \mathrm{~b}$ \\
\hline 11.06/PWR/B/0386 & $\sqrt{ }$ & & Keris Tipe 4 b \\
\hline 11.06/PWR/B/0395 & & $\sqrt{ }$ & Keris Tipe 5 \\
\hline 11.06/PWR/B/-- & $\sqrt{ }$ & & Keris Tipe 6 \\
\hline 11.06/PWR/B/0011 & $\sqrt{ }$ & & Pedang Tipe 1 \\
\hline 11.06/PWR/B/0036 & $\sqrt{ }$ & & Mata Tombak Tipe 1 \\
\hline 11.06/PWR/B/0120 & $\sqrt{ }$ & & Mata Tombak Tipe 2 \\
\hline
\end{tabular}


mulai dari 0,01 - 100\% pada sampel dengan ketebalan maksimal 2 mm (Shackley, 2011: 8-9). Langkah kerja metode tersebut adalah sebagai berikut :

\section{Pancaran Sinar X (XRF)}

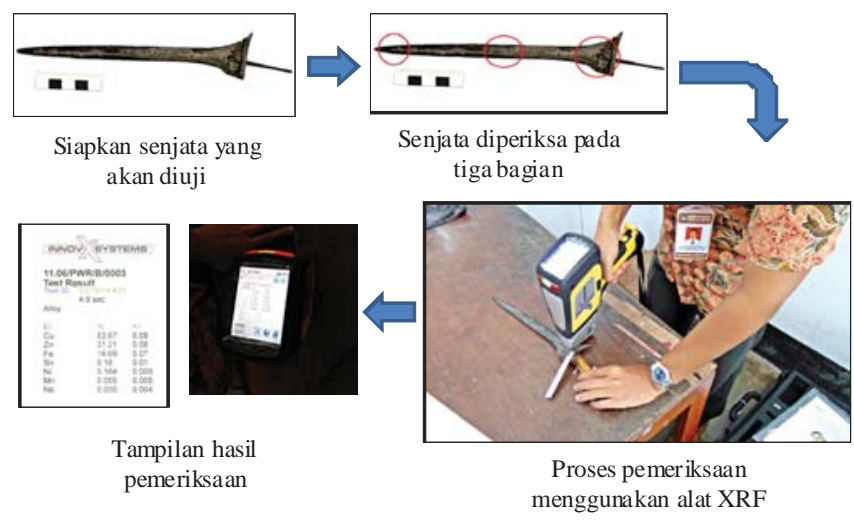

Gambar 1. Langkah kerja metode pancaran sinar $\mathrm{x}$ Pengukuran Kekerasan Skala Mohs

\section{Pengukuran Kekerasan Skala Mohs}

Skala Mohs adalah skala kekerasan relatif yang umum diterapkan pada bidang mineralogi. Skala tersebut memiliki derajat kekerasan dari 1 - 10 yang mana setiap derajat mewakili jenis mineral yang dikenal secara luas (Klein dan Hurlbut, 1977: 203). Angka 1 menunjukkan mineral yang paling lunak dan angka 10 menunjukkan mineral yang paling keras. Langkah kerja metode tersebut adalah sebagai berikut :

\section{Pembahasan}

Hasil analisis menggunakan metode pancaran

Pengukuran Kekerasan Skala Mohs

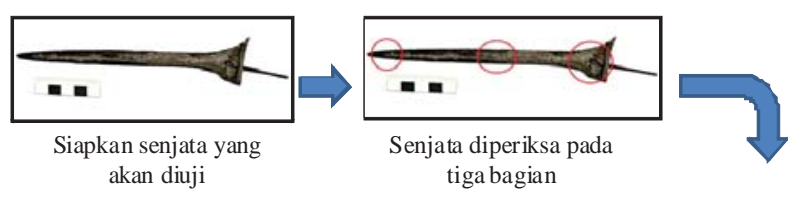

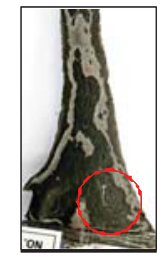

Tampilan bekas pengukuran

Gambar 2. Langkah kerja metode skala Mohs

sinar x menunjukkan unsur yang dapat dikenali pada senjata logam adalah Fe, Ni, Re, Cu, Sn, Cr, Au, Mn, Zn, dan Nb. Tidak ditemukan senjata dengan susunan unsur yang sama. Hasil selengkapnya ditampilkan pada tabel 4.

Tidak ditemukan suatu pola trace element yang sama pada seluruh senjata yang dianalisis. Setiap jenis senjata dari tipe yang berbeda memiliki pola susunan trace element yang berbeda pula. Pada senjata dari tipe yang sama dan diasumsikan berasal dari masa pembuatan (tanggub) yang sama juga tidak ditemukan pola trace element yang serupa. Pola trace element yang berbeda dapat mengindikasikan :

1) Senjata-senjata tersebut terbuat dari sumber logam yang berbeda.

2) Senjata-senjata tersebut terbuat dari sumber logam yang sama, namun dalam pengerjaannya

Tabel 4. Kandungan unsur pada senjata

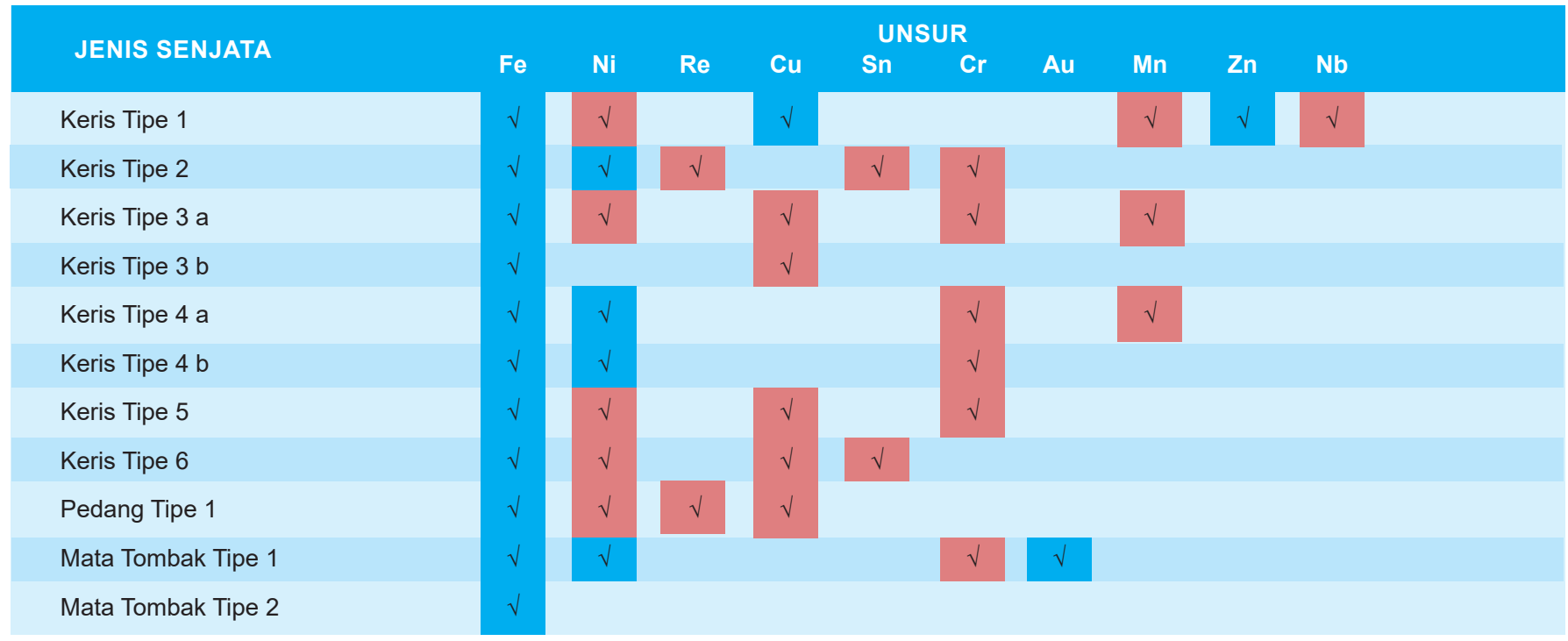

Keterangan : Warna biru menunjukkan unsur penyusun utama (lebih dari 1\%), sedangkan warna merah menunjukkan trace element (kurang dari $1 \%)$ 
Tabel 5. Senjata yang memiliki pamorwos wutah

\begin{tabular}{|c|c|c|c|c|c|c|c|c|c|c|c|}
\hline \multirow{2}{*}{ JENIS SENJATA } & \multicolumn{10}{|c|}{ UNSUR } & \multirow{2}{*}{ JENIS SENJATA } \\
\hline & $\mathrm{Fe}$ & $\mathbf{N i}$ & $\operatorname{Re}$ & $\mathrm{Cu}$ & Sn & $\mathrm{Cr}$ & $\mathrm{Au}$ & Mn & $\mathrm{Zn}$ & $\mathrm{Nb}$ & \\
\hline Keris Tipe 1 & $\sqrt{ }$ & $\sqrt{ }$ & & $\sqrt{ }$ & & & & $\sqrt{ }$ & $\sqrt{ }$ & $\sqrt{ }$ & Wos Wutah \\
\hline Keris Tipe 2 & $\sqrt{ }$ & $\sqrt{ }$ & $\sqrt{ }$ & & $\sqrt{ }$ & $\sqrt{ }$ & & & & & Wos Wutah \\
\hline Keris Tipe $3 \mathrm{~b}$ & $\sqrt{ }$ & & & $\sqrt{ }$ & & & & & & & Wos Wutah \\
\hline Keris Tipe $4 \mathrm{~b}$ & $\sqrt{ }$ & $\sqrt{ }$ & & & & $\sqrt{ }$ & & & & & Wos Wutah \\
\hline Keris Tipe 5 & $\sqrt{ }$ & $\sqrt{ }$ & & $\sqrt{ }$ & & $\sqrt{ }$ & & & & & Wos Wutah \\
\hline
\end{tabular}

ditambahkan campuran logam (bahan pamor) yang berbeda, dalam jumlah yang kecil.

3) Sampel yang dianalisis tidak cukup banyak, sehingga pola yang sesuai tidak muncul.

Hubungan antara kandungan unsur dan pamor pada senjata dianalisis dari lima senjata dari tipe berbeda yang memiliki jenis pamor yang sama, yaitu pamor wos wutah. Hasil analisis menujukkan lima senjata tersebut memiliki kandungan unsur yang berbeda. Data hasil analisis menunjukkan pamor, khususnya wos wutah, terbentuk tanpa pengaruh dari jenis bahan logam yang digunakan.

Pengukuran tingkat kekerasan menunjukkan hasil yang bervariasi mulai dari 3 hingga 6 skala Mohs. Hasil pengukuran kekerasan ditunjukkan pada tabel berikut :

Pedang dan Mata Tombak memiliki tingkat kekerasan 5 skala Mohs, sedangkan rata-rata Keris memiliki tingkat kekerasan 4,16. Tampaknya hal ini berhubungan dengan fungsi. Pedang dan mata tombak umumnya merupakan senjata yang lebih sering digunakan dalam peperangan (Solyom dan Solyom, 1978: 26; Harsrinuksmo, 1991: 68), sehingga dibuat dengan tingkat kekerasan yang lebih tinggi dari pada keris. Tingkat kekerasan yang tinggi merupakan unsur yang penting dalam daya tahan senjata saat digunakan di peperangan. Selain itu sangat mungkin pedang dan mata tombak lebih sering digunakan dalam peperangan karena jangkauannya yang lebih jauh dari pada keris.

Tingkat kekerasan yang dianggap mewakili teknologi pembuatan keris tentu tidak dapat dilepaskan dari proses pembuatan sebuah keris. Proses paling penting dalam pembuatan keris adalah proses pelipatan untuk menyatukan semua bahan. Berdasarkan ciri tangguh dapat diketahui berapa jumlah lipatan pada keris-keris tersebut.

Jika tabel diatas dikonversikan menjadi sebuah grafik, akan tampak hubungan antara jumlah lipatan dengan tingkat kekerasan. Semakin banyak jumlah lipatan, maka semakin tinggi pula tingkat kekerasan pada

Tabel 6. Hasil pengukuran tingkat kekerasan (dalam Skala Mohs)

\begin{tabular}{|lcccc}
\hline JENIS SENJATA & \multicolumn{3}{c}{ TINGKAT KEKERASAN } & \multicolumn{2}{c}{ TINGKAT KEKERASAN } \\
\hline RANGKAL & TENGAH & UJUNG & 3,7 \\
\hline Keris Tipe 1 & 4 & 3 & 4 & 5 \\
\hline Keris Tipe 2 & 5 & 5 & 5 & 4,3 \\
\hline Keris Tipe 3 a & 4 & 5 & 4 & 4 \\
\hline Keris Tipe 3 b & 4 & 4 & 4 & 4 \\
\hline Keris Tipe 4 a & 4 & 4 & 4 & 4 \\
\hline Keris Tipe 4 b & 4 & 4 & 4 & 4,3 \\
\hline Keris Tipe 5 & 4 & 5 & 4 & 4 \\
\hline Keris Tipe 6 & 4 & 4 & 4 & 5 \\
\hline Pedang Tipe 1 & 5 & 5 & 5 & 5 \\
\hline Mata Tombak Tipe 1 & 5 & 5 & 5 & 5 \\
\hline Mata Tombak Tipe 2 & 6 & 5 & 4 & 5
\end{tabular}


Tabel 7. Tipe Keris yang diasumsikan mewakili tangguh tertentu

\begin{tabular}{|lccc}
\hline TANGGUH & TIPE & Lipatan & $\begin{array}{c}\text { TINGKAT } \\
\text { KEKERASAN }\end{array}$ \\
\hline Pajajaran & Keris Tipe 4 & 64 & 4 \\
Majapahit & Keris Tipe 2 & 2048 & 5 \\
Pajang & Keris Tipe 6 & 128 & 4 \\
Mataram & Keris Tipe 3 & 256 & 4,15 \\
\hline
\end{tabular}

keris tersebut. Grafik ditampilkan pada Gambar 3.

Jika hasil analisis unsur dan kekerasan dihubungkan dalam satu tabel, akan menunjukkan hasil sebagai berikut :

Banyaknya jenis unsur penyusun pada senjata tampaknya tidak memiliki hubungan dengan tingkat kekerasan pada senjata tersebut. Hubungan antara unsur penyusun dan tingkat kekerasan pada senjata dapat dijelaskan melalui persentase kadar besi (Fe) pada senjata yang ditampilkan pada tabel 10 .

Keris Tipe 1 yang memiliki persentase Fe kurang dari 70\% menghasilkan senjata dengan tingkat kekerasan rendah (3,7 skala Mohs), sementara senjata lain yang memiliki kandungan unsur besi $(\mathrm{Fe})$ dengan persentase lebih dari $80 \%$ menunjukkan tingkat kekerasan yang relatif tinggi antara $4-5$ skala Mohs. Berdasarkan uraian tersebut, banyaknya persentase unsur besi (Fe) yang digunakan dalam pembuatan senjata dapat mempengaruhi tingkat kekerasan senjata tersebut.

\section{Kesimpulan}

Dari hasil analisis kandungan unsur yang dilakukan terhadap 11 bilah senjata, tidak menunjukkan adanya pola komposisi unsur yang serupa, bahkan pada senjata dari jenis maupun tipe yang sama. Sementara pada analisis terhadap trace element juga tidak ditemukan suatu keteraturan pola yang muncul. Dari 11 bilah senjata semuanya memiliki susunan pola trace element yang berbeda. Hal ini mengindikasikan bahwa semua senjata tersebut dibuat dari sumber bahan besi yang berbeda, atau kemungkinan lain, beberapa senjata tersebut bisa saja dibuat dari sumber bahan yang sama, tetapi pada saat proses pembuatan ditambahkan bahan pamor yang berbeda.

Pada analisis terhadap pamor menunjukkan bahwa tidak ada hubungan antara komposisi unsur dengan pamor. Pada lima keris ber-pamor wos wutah yang dianalisis, tidak menunjukkan adanya hubungan antara pamor dengan komposisi unsur logam penyusunnya. Hal ini dapat menjadi indikasi bahwa pamor wos wutah terbentuk secara tidak disengaja oleh pembuat keris.

Dari analisis terhadap tingkat kekerasan senjata rupanya dapat menunjukkan teknologi pembuatan senjata logam pada masa lampau. Hasil analisis ini menunjukkan bahwa pedang dan mata tombak memiliki

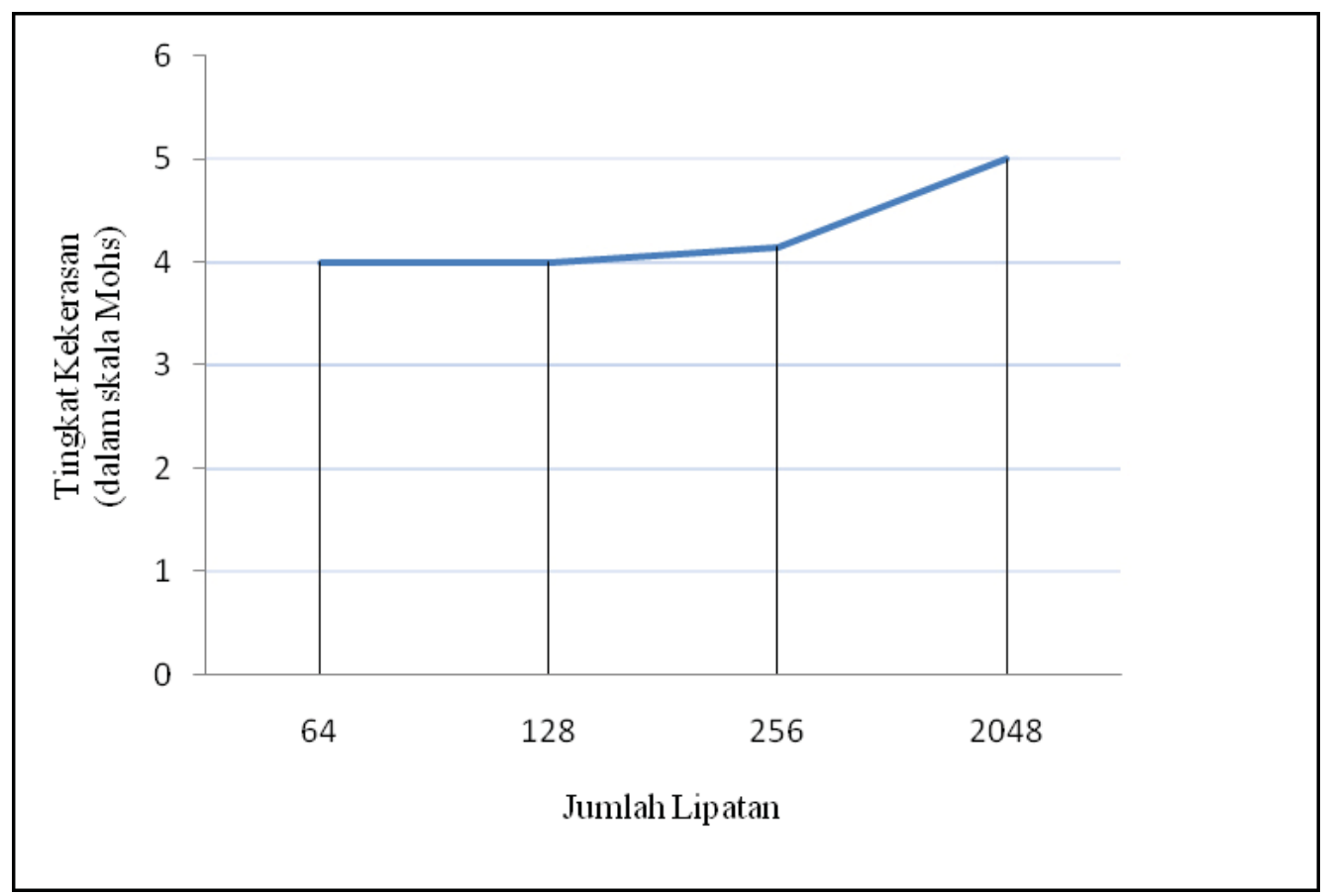

Gambar 3. Hubungan antara jumlah lipatan dengan tingkat kekerasan pada keris 
Tabel 8. Hubungan antara unsur dan tingkat kekerasan pada senjata

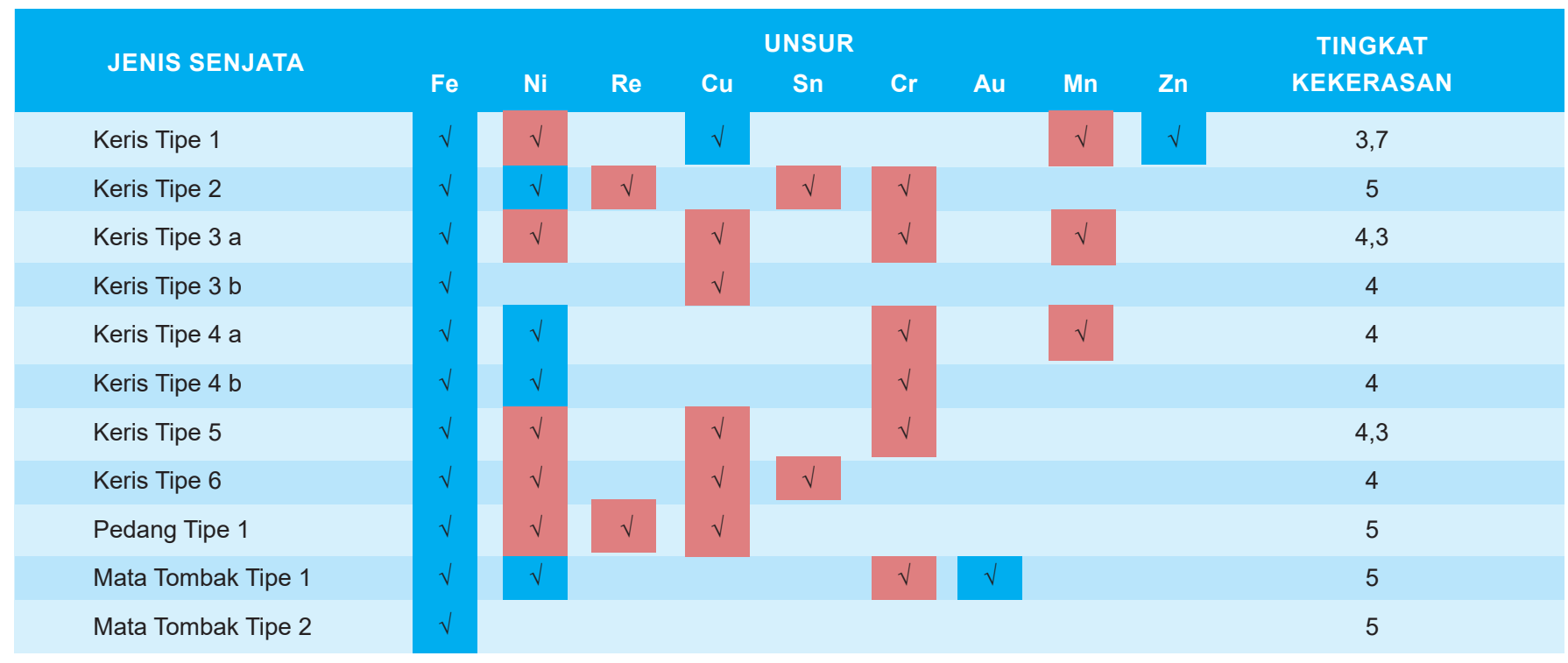

Keterangan : Warna biru menunjukkan unsur penyusun utama (lebih dari 1\%), sedangkan warna merah menunjukkan trace element (kurang dari $1 \%)$.

Tabel 10. Hubungan antara persentase besi (Fe) dan tingkat kekerasan pada senjata

\begin{tabular}{|c|c|c|c|c|}
\hline JENIS SENJATA & TITIK UJI & $\% \mathrm{Fe}$ & TINGKAT KEKERASAN & TINGKAT KEKERASAN RATA-RATA \\
\hline \multirow{3}{*}{ Keris Tipe 1} & Pangkal & 14,69 & 4 & \multirow{3}{*}{3,7} \\
\hline & Tengah Bilah & 68,58 & 3 & \\
\hline & Ujung & 59,97 & 4 & \\
\hline \multirow{3}{*}{ Keris Tipe 2} & Pangkal & 96,98 & 5 & \multirow{3}{*}{5} \\
\hline & Tengah Bilah & 98,17 & 5 & \\
\hline & Ujung & 97,16 & 5 & \\
\hline \multirow{3}{*}{ Keris Tipe 3 a } & Pangkal & 99,59 & 4 & \multirow{3}{*}{4,3} \\
\hline & Tengah Bilah & 99,21 & 5 & \\
\hline & Ujung & 99,24 & 4 & \\
\hline \multirow{3}{*}{ Keris Tipe $3 b$} & Pangkal & 99,83 & 4 & \multirow{3}{*}{4} \\
\hline & Tengah Bilah & 100 & 4 & \\
\hline & Ujung & 99,57 & 4 & \\
\hline \multirow{3}{*}{ Keris Tipe 4 a } & Pangkal & 99,96 & 4 & \multirow{3}{*}{4} \\
\hline & Tengah Bilah & 98,27 & 4 & \\
\hline & Ujung & 98,68 & 4 & \\
\hline \multirow{3}{*}{ Keris Tipe $4 \mathrm{~b}$} & Pangkal & 99,974 & 4 & \multirow{3}{*}{4} \\
\hline & Tengah Bilah & 99,53 & 4 & \\
\hline & Ujung & 99,25 & 4 & \\
\hline \multirow{3}{*}{ Keris Tipe 5} & Pangkal & 99,17 & 4 & \multirow{3}{*}{4,3} \\
\hline & Tengah Bilah & 99,19 & 5 & \\
\hline & Ujung & 99,49 & 4 & \\
\hline \multirow{3}{*}{ Keris Tipe 6} & Pangkal & 99,26 & 4 & \multirow{3}{*}{4} \\
\hline & Tengah Bilah & 99,4 & 4 & \\
\hline & Ujung & 99,63 & 4 & \\
\hline \multirow{3}{*}{ Pedang Tipe 1} & Pangkal & 99,61 & 5 & \multirow{3}{*}{5} \\
\hline & Tengah Bilah & 99,88 & 5 & \\
\hline & Ujung & 99,82 & 5 & \\
\hline \multirow{3}{*}{ Mata Tombak Tipe 1} & Pangkal & 96,69 & 5 & \multirow{3}{*}{5} \\
\hline & Tengah Bilah & 81,78 & 5 & \\
\hline & Ujung & 99,62 & 5 & \\
\hline \multirow{3}{*}{ Mata Tombak Tipe 2} & Pangkal & 100 & 6 & \multirow{3}{*}{5} \\
\hline & Tengah Bilah & 100 & 5 & \\
\hline & Ujung & 100 & 4 & \\
\hline
\end{tabular}


tingkat kekerasan rata-rata di atas keris, yaitu sebesar 5 skala Mohs dibandingkan keris yang hanya sebesar 4,16 skala Mohs. Tampaknya hal ini memiliki hubungan dengan fungsi dari tiap jenis senjata. Pedang dan tombak lebih utama digunakan dalam peperangan karena jangkauannya yang lebih jauh memberikan keuntungan bagi penggunanya. Keris tampaknya lebih berfungsi sebagai senjata pamungkas yang digunakan jika telah terdesak.

Selain tingkat kekerasan antar jenis senjata, analisis terhadap tingkat kekerasan menunjukkan bahwa tingkat kekerasan keris dari tipe yang berbeda memiliki perbedaan satu sama lain. Keris Tipe 1 menunjukkan tingkat kekerasan paling rendah yaitu 3,7 skala Mohs, sedangkan Keris Tipe 5 memiliki tingkat kekerasan paling tinggi yaitu 5 skala Mohs. Keris Tipe lainnya yaitu Tipe 3,4, 5, dan 6 memiliki tingkat kekerasan menengah antara 4 - 4,3 skala Mohs. Perbedaan tingkat kekerasan ini dapat dihubungkan dengan proses pembuatan pada keris. Berdasarkan kemiripan morfologi, diperoleh beberapa

\section{DAFTAR PUSTAKA}

Childe, V.G. 1950. The urban revolution. Liverpool Press: Town Planning Review, Vol. 21, No. 1, (April. 1950), pp. 3-17.

Djomul, Mas. 1985. Keris, benda budaya. Jakarta: Aksara Baru bekerja sama dengan Taman Mini Indonesia Indah.

Fagan, B. M. 1975. In the beginning, an introduction to archaeology. Boston: Little, Brown and Company.

Goffer, Z. 1980. Archaeological chemistry. New York: John Wiley \& Sons.

Hamzuri. 1988. Keris. Penerbit Djambatan.

Haryono, Timbul. 1999. Arkeologi metalurgi: Perannya dalam eksplanasi arkeologi. Makalah dalam Evaluasi Hasil Penelitian Arkeologi, Lembang, 22-26 Juni 1999. 1983. Arkeometalurgi: Prospeknya dalam penelitian arkeologi di Indonesia. Makalah dalam Pertemuan Ilmiah Arkeologi III, Ciloto 23-28 Mei 1983.

Harsrinuksmo, Bambang. 2008. Ensiklopedia keris. Jakarta:

PT Gramedia Pustaka Utama.
Tipe Keris dalam penelitian ini yang dapat digunakan mewakili tingkat kekerasan keris tangguh tertentu.

Tingkat kekerasan pada keris-keris tersebut berbanding lurus dengan kerumitan pengerjaannya. Keris dengan jumlah lipatan sedikit menunjukkan tingkat kekerasan yang rendah dan sebaliknya keris dengan jumlah lipatan lebih banyak menunjukkan tingkat kekerasan yang tinggi. Hal tersebut menunjukkan bahwa semakin rumit dan banyak jumlah pelipatan pada saat proses pembuatan keris semakin tinggi pula kualitas keris yang dihasilkan.

Dari serangkaian analisis yang telah dilakukan diketahu bahwa komposisi unsur tidak memiliki hubungan langsung dengan tingkat kekerasan pada senjata. Unsur yang memiliki pengaruh pada tingkat kekerasan hanya besi $(\mathrm{Fe})$, semakin rendah persentase kandungan besi $(\mathrm{Fe})$ semakin rendah pula tingkat kekerasan senjata tersebut. Sebaliknya, persentase besi $(\mathrm{Fe})$ yang tinggi pada senjata menghasilkan senjata dengan tingkat kekerasan yang tinggi pula.

Huda, Arief Syaifuddin. 2010. Sejarah Keris. Jakarta: DFS Publisher.

Klein, C., \& Hurlbut, Jr, C.S. 1977. Manual of mineralogy (after James D. Dana). New York: John Wiley \& Son

Moebirman. 1970. Keris and other weapons of Indonesia. Jakarta: Yayasan PelitaWisata.

Prijono, Sudarti. 2000. Artefak logam perunggu masa lampau, suatu komoditi perdagangan di awal masehi. Artikel dalam Fachroel Aziz dan Etty Saringendyanti (Ed). Cakrawala Arkeologi, Balai Arkeologi Bandung.

Shackley, M.S. 2011. X-ray fuorescence spectrometry in geoarchaeology. Springer Science + Business Media.

Solyom, G., \& Solyom, B. 1978. The world of the Javanese keris. Honolulu: East-West Center

Watson, P. J., et al. 1971. Explanation in archaeology, an explicitly scientific approach. New York: Columbia University Press

Wibawa, Prasida. 2008. Tosan Aji pesona jejak prestasi budaya. Jakarta: PT Gramedia Pustaka Utama. 